\title{
SUBSTANTIATION OF EFFECTIVENESS OF TRAININGS ON HEALTH RELATED METHODIC FOR STUDENTS WITH WEAKENED MOTOR FITNESS
}

\author{
Kuzmin V.A. ${ }^{1}$, Kopylov Yu.A. ${ }^{2}$, Kudryavtsev M.D. ${ }^{1}$, Galimov G.Y. ${ }^{3}$, Iermakov S. S. ${ }^{4}$ \\ ${ }^{1}$ Siberian Federal University, Russia \\ ${ }^{2}$ Institute of Developmental Physiology, Russia \\ ${ }^{3}$ Buryat State University, Russia \\ ${ }^{4}$ Kazimierz Wielki University in Bydgoszcz, Poland
}

\begin{abstract}
Purpose: to work out methodic, facilitating successful conduct of health related trainings of students withy weakened motor (physical) fitness. Material: in the research 47 students with weakened motor fitness participated. Analysis of indicators of morbidity frequency and duration was carried out on the base of medical records' studying during all academic year. Experimental methodic consisted of three chapters: execution of specifically selected Hatha yoga static postures, breathing exercises and boxing techniques. Breathing exercises were grouped in four complexes. Every complex was fulfilled during 6 trainings, after each of them the next followed. Results: it was found that frequency and duration of diseases statistically confidently decreased in academic year. It was shown that formation of healthy life style skills statistically confidently improved. Conclusions: we have determined: increased students' interest to physical culture practicing; reduction of frequency and duration of diseases; higher level of formation of healthy life style skills.
\end{abstract}

Key words: students, health improvement, methodic, diseases, fitness.

\section{Introduction}

Health related measures, reduced as usual to formation of body health - increase of functional fitness, resistance to colds, corrections of muscular skeletal apparatus and some other aspects,- were always paid rather close attention to [2]. Alongside with it there are the data, saying that it is practically impossible to selectively improve physiological aspects of health in isolation from psychic and social-moral health [21]. It complies with law of "relative independence of adaptation", which says: high adaptability to one factor does not result in the same adaptability to other factors (and on the contrary: such adaptability can restrict adaptation due to organism's physiological-morphological characteristics). Therefore, for motor, psychic and social-moral components of health it is necessary to build certain academic programs, which can critically differ from each other [20]. Up to the present time the law of "relatively independent adaptation" has not found its proper place in learning educational process of educational establishments. It is especially important to consider this law in educational system of higher educational establishments, where students already have serious deviations in health, acquired in school years [3].

Rising of students' motivation for physical culture - sport activity is regarded as one of priority directions of educational process perfection in HEE [5, 15, 24]. A number of factors, influencing on attitude to physical culture has been found. It was determined that the most significant for development of students and youth's physical culture were: rising of youth's interest to physical culture practicing $[16,22]$; effective administrating of youth's physical education and physical training [14, 18]; orientation of students' physical education of formation of healthy life style $[17,23]$.

Purpose, tasks of the work, material and methods

The purpose of the work: is to work out methodic, facilitating successful conduct of health related trainings of students withy weakened motor (physical) fitness.

In the research 47 students of higher educational establishments with weakened motor fitness participated.

When planning academic program for experimental group we considered recommendations of methodic literature on formation of training process for students with weakened motor functioning.

\section{Results of the research}

(C) Kuzmin V.A., Kopylov Yu.A., Kudryavtsev M.D.,

Galimov G.Y., lermakov S. S., 2015

http://dx.doi.org/10.15561/20755279.2015.0606 
The conducted by us complex researches on determination of students' social-moral health features revealed some important laws. We found correlation between the level of some motor qualities and socially significant features of students. Analysis of final results of students' fitness showed that the worked out experimental program facilitated more effective development of nearly all indicators.

Positive points of the experimental methodic is the fact that at the end of pedagogic experiment the students' studied indicators demonstrated statistically confident improvement: quantity and duration of diseases reduced; students' interest to physical culture practicing and level of healthy life style skills increased.

It can be explained by the fact that trainings with elements of boxing permits to make training of new motor skills more interesting, emotional; it shortens period of mastering of new material. Thus, it increases effectiveness of students' mastering discipline "Physical culture".

\section{Determination of diseases' frequency and duration}

Indicators of frequency and duration of diseases were studied on the base of medical records' analysis during academic year. We considered the quantity of diseases (see table 1) their duration (quantity of days - see table 2) during academic year.

Initial data of quantity and duration of diseases were taken by results of previous year.

Table 1. Quantity of diseases $(\mathrm{M}+\mathrm{m}, \%)$

\begin{tabular}{lllcc}
\hline $\begin{array}{l}\text { Testing } \\
\text { Initial }\end{array}$ & Final & Differences & \multicolumn{2}{c}{ Confidence of differences } \\
& & $\mathrm{t}$ & $\mathrm{p}$ \\
\hline $52.1 \pm 3.8$ & $41.8 \pm 3.3$ & 10.3 & 2.05 & $<0.05$ \\
\hline
\end{tabular}

Quantity of diseases in academic year is statistically confident $(\mathrm{p}<0.05)$ below. Duration of diseases (in days) was as follows (see table 2).

Table 2. Duration of diseases (in days) $(\mathrm{M} \pm \mathrm{m}, \%)$

\begin{tabular}{lllcc}
\hline $\begin{array}{l}\text { Testing } \\
\text { Initial }\end{array}$ & Final & Differences & \multicolumn{2}{c}{ Confidence of differences } \\
\hline $113.2 \pm 3.7$ & $98.7 \pm 4.8$ & & $\mathrm{t}$ & $\mathrm{p}$ \\
\hline
\end{tabular}

Analysis of comparative data showed that students, who were trained by experimental methodic with application of boxing elements were more resistant to different diseases: by quantity of cases and by duration of diseases $(\mathrm{p}<0.05)$.

\section{Formation of healthy life style skills}

Final data (received in pedagogic experiment) showed statistically confident increase $(\mathrm{p}<0.05)$ of healthy life style skills' formation level (see table 3).

Table 3. Indicators of healthy life style skills' level, conv. units $(\mathrm{M} \pm \mathrm{m})$

\begin{tabular}{lllll}
\hline Testing & & Confidence & of \\
Initial & Final & Differences & \multicolumn{2}{l}{$\begin{array}{l}\text { differences } \\
\mathrm{t}\end{array}$} \\
\hline $40.3 \pm 8.0$ & $65.4 \pm 8.2$ & 25.1 & $\mathrm{p}$ & \\
\hline
\end{tabular}

Analysis of the received data showed that application of health related methodic with boxing techniques permits to significantly increase level of healthy life style skills' formation in students with weakened motor fitness.

\section{Assessment of interest to trainings}


As our researches showed, initial interest of students with weakened motor fitness to physical culture and sports practicing did not exceed values, close to 3.77 points (by five-point scale).

After pedagogic experiment we found confident $(\mathrm{p}<0.05)$ data of interest increase in students with weakened motor fitness (see table 4).

Table 4. Indicators of level of interest (points) to trainings in students of control and experimental groups at the end of pedagogic experiment $(\mathrm{M} \pm \mathrm{m})$

\begin{tabular}{lllrc}
\hline Testing & & \multirow{2}{c}{ Differences } & \multicolumn{2}{c}{ Confidence of differences } \\
Initial & Final & & $\mathrm{t}$ & $\mathrm{p}$ \\
\hline $3.77 \pm 0.1$ & $4.09 \pm 0.1$ & 0.32 & 2.26 & $<0.05$ \\
\hline
\end{tabular}

Such positive results permit to state that interest of students to trainings can be formed for relatively short period of time (one academic year).

\section{Discussion}

At present the problem of physical education system's perfection, health strengthening and protection in period of students' studying in HEE is noticeably actualized. This system requires new scientific approaches and methodically substantiated solutions.

To day's attention of specialists to this problem to large extent is conditioned by intensive increasing of a number of negative tendencies, which accompany students' physical education. It is confirmed by the fact that the question about "aggressiveness of educational medium" has never been so acute; students' health indicators have never been so low; such low physical condition and motor fitness indicators have never been registered [10, 2527].

Analysis of published literature showed that at present time individual features of students' physical condition, health, motor fitness, personality's characteristics (motives, strivings, self-confidence and so on) have been elucidated rather sparingly [13-17]. The limit of such data seriously hinders the process of students' professional adaptation in educational medium.

We assumed that the problems, which are faced by pedagogues and coaches in sphere of students' physical education, can be corrected with means and methods of boxing. As it was found traditional physical education system in state higher educational establishments can not realize to the fullest extent the tasks of students' motivation for physical culture activity. It is connected with absence of scientifically substantiated conception of physical education formation [11-13, 19].

The fulfilled in this direction scientific and methodic work permitted, in the whole, to rather effectively organize learning regime in higher school, to level the acuteness of problem of organism's overloading in conditions of educational process, to maintain students' workability in relatively optimal frames. The distinctive features of our research are the following:

1. We have developed the system of complex improvement of students' with weakened motor fitness indicators.

Experimental methodic consisted of three parts: execution of specially selected statics postures (asanas) of Hatha yoga system, breathing training and boxing techniques.

Breathing exercises were grouped in four complexes. Every complex was fulfilled during 6 trainings, after each of them the next followed.

Boxing part included main techniques: movements, straight and side punches, uppercuts, defenses.

2. We have worked out methodic of usage of complex system for improvement of students' with weakened motor fitness indicators.

All static exercises were fulfilled consequently one after other. After fulfillment of exercises students had passive rest in lying position.

Breathing exercises were fulfilled after Hatha yoga static postures in position sitting on heels.

\section{Conclusions}

Thus, content of auxiliary (health related) physical culture training implies some knowledge, skills and abilities, which should be mastered by students. Prevailing orientation of such trainings is orientation on health 
related, developing and general recreational tasks. With it formation of physical, psychic and social-moral health should be of preference as well as personality-oriented approach to system of individual choice of physical culture means. Application of non traditional health related means, like Hatha yoga, will be highly effective in system of students' physical education. It is also important to use the principle of versatility. It permits to use knowledge and means of auxiliary health related physical culture in different regions of country and for students with different levels of physical culture literacy and fitness [4, 6-10].

The conducted pedagogic experiment with students, who have weakened motor fitness, showed the following:

1. Frequency and duration of diseases during academic year confidently $(p<0.05)$ reduced accordingly from $52.1 \pm 3.8$ to $41.8 \pm 3.3$; and from $113.2 \pm 3.7$ to $98.7 \pm 4.8$ days.

2. Formation of healthy life style skills statistically confidently $(\mathrm{p}<0.05)$ increased from $40.3 \pm 8.0$ to 65.4 \pm 8.2 convenient units.

3. After pedagogic experiment interest for physical culture trainings confidently increased $(p<0.05)$ from $3.77 \pm 0.1$ to $4.09 \pm 0.1$ points.

4. The experimental methodic is effective and has specificity - increase of interest to physical; culture trainings by students on the base of the following: reduction of frequency and duration of diseases; conscious and firm skills of healthy life style.

\section{Conflict of interests}

The authors declare that there is no conflict of interests.

\section{References:}

1. Gruzhevsky VA. Appropriateness of the use of innovative technologies in the formation of personality oriented motivation of students to physical education. Pedagogics, psychology, medical-biological problems of physical training and sports, 2014;3:19-24. . http://dx.doi.org/10.6084/m9.figshare.936958

2. Zajcev GK. Valeologo-pedagogicheskie osnovy obespecheniia zdorov'ia cheloveka v sisteme obrazovaniia. Doct. Diss. [Valueological - pedagogic principles of ensuring of human health in educational system. Doct. Diss.], Sankt Petersburg; 1998. (in Russian)

3. Kopylov IuA, Kokova EI, Polianskaia NV. Razrabotka ozdorovitel'nogo bloka v sisteme fizicheskogo vospitaniia studentov vysshikh uchebnykh zavedenij [Development of health related block in system of higher educational establishment students' physical education]. Vserossijskaia nauchno-prakticheskaia konferenciia «Optimizaciia uchebno-vospitatel'nogo i trenirovochnogo processa $v$ uchebnykh zavedeniiakh vysshego professional'nogo obrazovaniia». 22 fevralia 2012 g. Krasnoiarsk [All-Russian scientific-practical conference "Optimization of learning-educational and training process in educational establishments of higher vocational training” February 22nd, 2012, Krasnoyarsk], Krasnoyarsk; 2012. P. 374-379, (in Russian)

4. Kopylov YuA, Jackowska LN, Kudryavtsev MD, Kuzmin VA, Tolstopyatov IA, Iermakov SS. The concept of structure and content of health related trainings for higher educational establishments' students. Physical Education of Students, 2015;5:23-30. http://dx.doi.org/10.15561/20755279.2015.0504

5. Kosyns'kyi EO, Khodinov VM, Khrypliuk OP, Krot AS. Athletic and sporting interests of students in the physical education classes. Pedagogics, psychology, medical-biological problems of physical training and sports, 2013, vol.8, pp. 46-50. . http://dx.doi.org/10.6084/m9.figshare.745784

6. Kudriavcev MD, Galimov GIa, Gas'kov AV. Obosnovanie effektivnosti uchebnykh zaniatij po fizicheskoj kul'ture s ozdorovitel'noj i obrazovatel'noj napravlennost'iu na osnove ocenki pokazatelej ispol'zovaniia elementov zdorovogo obraza zhizni [Substantiation of effectiveness of health related and educational physical culture trainings on the base of assessment of healthy life style elements' usage]. Vestnik Buriatskogo gosudarstvennogo universiteta. 2012;13:121-124. (in Russian)

7. Kudriavcev MD, Galimov GIa, Strel'nikov VA. Organizaciia fizkul'turno-obrazovatel'noj deiatel'nosti v razvivaiushchem obuchenii [Organization of physical culture-educational activity in developing teaching]. Vestnik Buriatskogo gosudarstvennogo universiteta. 2012;1:97-105. (in Russian)

8. Kudriavcev MD, Konoshenko LA, Goncharova VG, Miadelec TN. Sociokul'turnaia reabilitaciia lic s ogranichennymi vozmozhnostiami zdorov'ia [Social-cultural rehabilitation of disabled persons]. Zhurnal Sibirskogo Federal'nogo universiteta. Gumanitarnye nauki. 2013;6(4):555-561. (in Russian); 
9. Kudriavcev MD, Galimov GIa. Ozdorovitel'naia napravlennost' uchebnykh zaniatij po fizicheskoj kul'ture [Health related orientation of academic physical culture lessons]. Vestnik Krasnoiarskogo gosudarstvennogo pedagogicheskogo universiteta. 2013;2:118-121. (in Russian)

10. Kuz'min VA, Kudriavcev MD, Kopylov IuA, Galimov GIa, Strel'nikov VA. Konceptual'nye osnovy neobkhodimosti obnovleniia dopolnitel'nogo ozdorovitel'nogo fizicheskogo vospitaniia studentov [Conceptual principles of demand in students' health related physical education's renewal]. Mezhdunarodnaia nauchno-prakticheskaia konferenciia "Molodaia sportivnaia nauka Belarusi", Minsk, 810 apr. 2014 g. [International scientific-practical conference "Young sport science of Belarus", Minsk, April 8th- 10th, 2014], Minsk BGUFK; 2014;2. P. 162-165.]. (in Russian)

11. Kuz'min VA, Kudriavcev MD, Galimov GIa, Kopylov IuA, Gas'kov AV. Sovremennye podkhody k sozdaniiu koncepcii i obnovleniiu struktury i soderzhaniia ozdorovitel'nogo fizicheskogo vospitaniia studentov vuzov [Modern approaches to creation of conception and renewal the structure and content of health related physical education of HEE students]. Vestnik Buriatskogo gosudarstvennogo universiteta. 2014;13:34-41. (in Russian)

12. Kuz'min VA, Kudriavcev MD, Galimov GIa, Kopylov IuA, Gas'kov AV. Effektivnost' ispol'zovaniia v sisteme fizicheskogo vospitaniia studentov netradicionnykh sredstv na primere khatkha-jogi [Effectiveness of non-traditional means' application in system of students' physical education on example of Hat ha Yoga]. Vestnik Buriatskogo gosudarstvennogo universiteta. 2014;13:41-44. (in Russian)

13. Kuz'min VA, Kudriavcev MD, Galimov GIa, Kopylov IuA, Gas'kov AV, Strel'nikov VA. Osobennosti formirovaniia social'no znachimykh lichnostnykh kachestv studentov-bokserov kak osnovy budushchej professional'noj deiatel'nosti [Peculiarities of formation of students-boxers' socially significant qualities as the basis of their future professional functioning]. Vestnik Buriatskogo gosudarstvennogo universiteta. 2014;13:68-72. (in Russian)

14. Panachev VD. Upravliaiushchaia rol' kafedry v razvitii fizicheskoj kul'tury i sporta v vuze [Leading role of physical culture department in development of physical culture and sports in HEE]. Teoriia i praktika fizicheskoj kul'tury 2004;1:49-52. (in Russian)

15. Parkhomchik VI. Faktory, vliiaiushchie na razvitie motivacii $\mathrm{v}$ fizkul'turno-sportivnoj deiatel'nosti studencheskoj molodezhi [Factors, influencing on development of motivation in students' physical culturesports activity]. 4 Respublikanskaia konferenciia "Tradicionnaia fizicheskaia kul'tura belorusov", 20 noiabria $2002 \mathrm{~g}$. [4th Republic conference "Traditional physical culture of Belarus people", November 20th, 2002], Minsk; 2002. P. 74-78 (in Russian)

16. Stoliarov VI, Kudriavcev NV. Novye formy fizkul'turno-sportivnoj raboty s uchashchejsia molodezh'iu [New forms of physical culture - sports work with students]. Fizicheskaia kul'tura 1998;1:21-26. (in Russian)

17. Shil'ko VG, Kapilevich LV, Guseva NL. Formirovanie zdorovogo obraza zhizni studentov cherez fizkul'turno-sportivnuiu deiatel'nost' [Formation of students' healthy life style through physical culture-sport functioning]. Mezhdunarodnaia nauchno-prakticheskaia konferenciia "Aktual'nye problemy sokhraneniia i ukrepleniia zdorov'ia molodezhi Sibirskogo regiona", 18-25 iiunia 2006 g. [International scientific-practical conference "Actual problems of health protection and strengthening of Siberian region youth", June 18th25th, 2006], Irkutsk; 2006. P 69. (in Russian)

18. Yurchyshyn YV. Modern information tools: their place in students' extra-curriculum and involvement of them in motor activity of health related orientation. Physical Education of Students, 2015;4:44-50. http://dx.doi.org/10.15561/20755279.2015.0407

19. Adashevskiy VM, Iermakov SS, Firsova IuIu. Physical mathematical modelling of difficult elements of acrobatic rock-and-roll. Physical Education of Students, 2013;3:3-10. doi:10.6084/m9.figshare.662463

20. Bar-or O. Health benefits of physical activity during childhood and adolescents. President's Council on Physical Fitness and Sports Physical Activity and Fitness Research Digest. 1995;2:1-8.

21. Bohm D. A New theory of the relationship of mind and body. J. Amer. Soc. Psych. Research. 1986;80(2):113-135.

22. Iermakova TS. Forming of healthylife style of pupils via prism of physical culture outside of school (historical aspect). Pedagogics, psychology, medical-biological problems of physical training and sports 2011;6:50-56. 
23. Iermakova TS. The peculiarities of work of the European network of health promoting schools (comparative analysis). Pedagogics, psychology, medical-biological problems of physical training and sports, 2013;10:8790. doi:10.6084/m9.figshare.775339

24. Iermakova TS. The usage by the modern school an experience of high school pupils' healthy life style forming (the second part of XX century). Pedagogics, Psychology, Medical-Biological Problems of Physical Training and Sports. 2010;11:34-37.

25. Podrigalo LV, Iermakov SS, Nosko MO, Galashko MN, Galashko NI. Study and analysis of armwrestlers' forearm muscles' strength. Journal of Physical Education and Sport, 2015;15(3):531-537. http://dx.doi.org/10.7752/jpes.2015.03080

26. Prusik Krzysztof, Prusik Katarzyna, Kozina ZhL, Iermakov SS. Features of physical development, physical preparedness and functional state of boys and girls - students of Polish higher educational establishments. Physical Education of Students, 2013;1:54-61. http://dx.doi.org/10.6084/m9.figshare.96415

27. Żukowska Hanna, Szark-Eckardt Mirosława, Muszkieta Radosław, Iermakova TS. Characteristics of body posture in the sagittal plane and fitness of first-form pupils from rural areas. Pedagogics, psychology, medical-biological problems of physical training and sports, 2014;7:50-60. http://dx.doi.org/10.6084/m9.figshare.1015583 


\section{Information about the authors: \\ Kuzmin V.A.; http://orcid.org/0000-0002-4190-1628; atosn35@mail.ru; Siberian Federal University; 79 Svobodny pr., Krasnoyarsk, 660041, Russia.}

Kopylov Yu.A.; http://orcid.org/0000-0002-3925-0483; yuko.47@mail.ru; Institute of Developmental Physiology; Pogodinskaya st., 8, k. 2, Moscow, 119869, Russia.

Kudryavtsev M.D.; http://orcid.org/0000-0002-4377-0879; kumid@yandex.ru; Siberian Federal University; Siberian State Aerospace University; 79 Svobodny pr., Krasnoyarsk, 660041, Russia.

Galimov G.Y.; http://orcid.org/0000-0003-0582-9283; tfk@bsu.ru; Buryat State University; Smolina st., 24a, UlanUde, 670000, Russia.

lermakov S.S.; http://orcid.org/0000-0002-5039-4517; sportart@gmail.com; Kazimierz Wielki University in Bydgoszcz; Chodkiewicza str. 30, 85-064 Bydgoszcz, Poland.

Cite this article as: Kuzmin V.A., Kopylov Yu.A., Kudryavtsev M.D., Galimov G.Y., Iermakov S.S. Substantiation of effectiveness of trainings on health related methodic for students with weakened motor fitness. Physical education of students, 2015;6:43-49. http://dx.doi.org/10.15561/20755279.2015.0606

The electronic version of this article is the complete one and can be found online at: http://www.sportpedu.org.ua/html/arhive-e.html

This is an Open Access article distributed under the terms of the Creative Commons Attribution License, which permits unrestricted use, distribution, and reproduction in any medium, provided the original work is properly cited (http://creativecommons.org/licenses/by/4.0/deed.en).

Received: 28.08.2015

Accepted: 06.09.2015; Published: 10.09.2015 